\title{
AN ANALYSIS ON SUSTAINABILITY OF SHARK UTILIZATION USING FISH RESOURCES AND FISHING TECHNIQUES APPROACH IN SELAYAR ISLAND REGENCY
}

\author{
Ziaul Haq Nawawi ${ }^{1}$, Natsir Nessa ${ }^{2}$, Dewi Yanuarita ${ }^{1}$, Muhammad Yusfi Yusuf $^{1}$, Sainal $^{1}$
}

Submitted: December 17, 2019 Accepted: March 2, 2020

\author{
1. Department of Management of Integrated Coastal Resources, Faculty of Marine Science and Fisheries University of \\ Hasanuddin \\ ${ }^{2}$.Department of Marine Science, Faculty of Marine Science and Fisheries, University of Hasanuddin \\ Corresponding author: \\ *Ziaul Haq Nawawi ${ }^{1}$. \\ Email: ziauleli@gmail.com
}

\begin{abstract}
The research aims to record the types of shark utilization in Selayar Islands Regency, explore the spread and shark status of the Regency of Selayar Islands, and examine the sustainability status of shark utilization by fisherman in Selayar Islands. The research method was based on the assessment of EAFM indicator assessments to assess the performance of shark resource management on Tarupa Island, Rajuni Island, Polassi Island and Kayuadi Island Selayar Islands Regency with an indicator approach involving two domains, i.e (1) Fish resources and (2) Fishing technique. The methods of obtaining the data were survey by extracting the data through interviews/questionnaire. The sample was determined using purposive sampling technique. The results of the research indicate that the status of utilizing shark fishery in Selayar Islands Regency is currently in medium category. The main issues indicated are a decrease in catch size and the catch of sharks that are not feasible to catch $(50 \%$ of catch $<\mathrm{Lm})$. The domains that need to get primary attention in the management of sharks fisheries are the domains of fish resources and fishing technique. The efforts of management carried out in each fields are based on central issues that emerge. Connectivity efforts between communities and institutions are needed to produce functional fisheries management status so that the sustainability of shark resources in Selayar Islands Regency can be sustainable
\end{abstract}

Keywords: EAFM, Sharks, Selayar Islands Regency

\section{INTRODUCTION}

Sharks are a fishery resource which has important value from ecological aspects which have a very wide habitat distribution from coastal watersheds, crossing continuous slopes to deep seas. Sharks and rays have very slow growth and take years to reach adulthood. As the top predator in the trophic level in the sea, sharks determine the balance of ecosystems in an aquatic area (WWF, 2016). According to Law No. 5 of 1990 concerning Conservation of Natural Resources and Ecosystems, it is explained that the management and utilization of biological natural resources is carried out wisely to ensure the sustainability of its supplies while maintaining and improving the quality of diversity and its value. Therefore, the preservation of sharks also continues to be carried out by the government, academics and practitioners in an effort to realize the rules that have been previously determined by carrying out planning to the establishment of applicable regulations.

PERMEN-KP No. 30 of 2012 concerning Capture Fisheries Business in the Territory of the Republic of Indonesia, specifically Article 73 paragraph 2 which gives instructions that by-catch of monkey sharks must be released back to the waters. Then in the following year
KEPMEN-KP No. 8 of 2013 concerning Determination of the Full Protection Status of the Whale Shark Rhincodon typus. In 2014 the government re-established PERMEN-KP No. 59 of 2014 concerning Prohibition of Spending Cowboy Shark Carcharhinus longimanus and Martil Shark Sphyrna spp. from the Territory of the Republic of Indonesia. According to personal observations in the waters of the Selayar Islands Regency, sharks are often caught by fishermen using longline. The capture of sharks in fishing gear is divided into two types of businesses. First, caught because the shark is a main target. Second, sharks caught accidently (by-catch) by fishing gear. The interesting thing about the shark market in Selayar have a difference price of each part of the body in the packaging process, 1 bunch of shark meat filled with 5 pieces of meat, dried meat are range only around $\mathrm{Rp}$ 10,000-15,000, while the dried fins are range of $75,000-2,000,000 / \mathrm{Kg}$.

The effort to regulate the capture of sharks until trade continues to be carried out by the government to maintain the sustainability of its resources. However, to implement the plan, valid and up-todate data are needed, so that planning is carried out on target and in accordance with the status of utilization. Based on the above description of the 
research conducted in the territorial waters in the Selayar Islands Regency with the consideration that shark catchers can be found in this area

\section{MATERIALS AND METHODS}

This research was conducted in March - September 2018 on several islands of the Selayar Islands Regency namely Tarupa Island, Rajuni Island , Polassi Island and Kayuadi Island.

The materials used in this study were questionnaire tools, data on resources and the fisheries environment in the Marine and Fisheries Service of Selayar Regency and other related agencies, while the tools used were as follows: Sabak, used as stationery during observation in research sites. The recorder, as a voice recorder when conducting interviews with respondents. Roll meters, measuring the length of the fish. Scales, used to measure fish weight. The camera, used to document activities during research. Global Positioning System (GPS), used to collect coordinates of fishing ground locations.

\section{Data collection}

The types of data collected are primary data and secondary data. Primary data collection is done through direct observation and recording in the field, interviews, and filling out the questionnaire. Interviews were conducted with shark-catching fishermen and the data collection was carried out by participating with fishermen while at sea.

\section{Primary}

Primary data collection was carried out using direct observation and measurement methods in the field, and structured interviews with the help of questionnaires. The activities undertaken in primary data collection include the following; Data collection on fishing ground points using GPS. Viewing the process of catching sharks. Viewing and recording the equipment and tools of sharks fishing. Collecting catches. Documenting activities during the trip. Calculating and recording the trip time. In collecting the data, fishermen catches by identifying species, counting the number of tails, and measuring length and weight. For identification of shark species based on the book identification of shark and ray species, namely Economically Important Sharks and Rays of Indonesia (White et al., 2006).

\section{Secondary}

Secondary data collection through literature study by collecting all information relating to the study in research from various related agencies.

\section{Respondents}

The number of respondents was determined using purposive sampling technique (Adrianto 2005; Sugiyono 2011). In this study, the number of sharkcatching fishermen in the Selayar Archipelago District were 9 people consisting of 5 people from Tarupa Island, 1 person from Rajuni Island, 2 people from Polassi Island and 1 person from Kayuadi Island.

\section{EAFM}

Data collected based on the purpose of this study includes four domains referring to the National Working Group Ecosystem Approach to Fisheries Management (NWG EAFM, 2014) module, namely: (1) The domain of fish resources and (2) The domain of capture technology (Table 1).

\section{Data Analysis}

The analysis in this study focused on the domain of fish resources and fishing techniques. Analysis of the data used a simple scoring system based on indicators that are assessed with a Likert-based Likert score of 1,2,3 whose category is the greater the score, the better the management action (KKP, 2014).

Furthermore, it was analyzed using a simple composite analysis based on arithmetic averages with five classification criteria displayed in the form of a flag model, Table 2 .

Table 2. EAFM composite analysis

\begin{tabular}{llll}
\hline \multicolumn{2}{l}{ Range value } & Model & Description \\
\cline { 1 - 2 } Low & High & Flag & \\
\hline 1 & 20 & & Poor \\
21 & 40 & & Less \\
41 & 60 & & Medium \\
61 & 80 & & Good \\
81 & 100 & & Excellent \\
\hline
\end{tabular}

\section{RESULTS AND DISCUSSION}

Status of shark fisheries management in the waters of Taka Bonerate National Park Selayar Islands District determined by the method EAFM uses four indicators. A description of the results of the analysis using the EAFM approach was described as follows: Fish Resource Domain

The EAFM approach in the fish resource domain contains five attributes that are measures of assessment of fish resource utilization activities, namely the size of the caught shark; Maturity; Species composition; Endangered, Threatened and Protected (ETP) species and location of capture 
Table 1. Domain, indicators, explanations, methodology and criteria EAFM

The domain of fish resources

\begin{tabular}{|c|c|c|c|c|c|}
\hline No & Indikator & Explanation & Methodology & Criteri & \\
\hline \multirow[t]{3}{*}{1} & \multirow{3}{*}{$\begin{array}{l}\text { Size of } \\
\text { shark } \\
\text { caught }\end{array}$} & \multirow{3}{*}{$\begin{array}{l}\text { Measurement of } \\
\text { total length (TL) }\end{array}$} & \multirow{3}{*}{$\begin{array}{l}\text { Sampling } \\
\text { Measurement } \\
\text { TL }\end{array}$} & 1: & The size of the smaller fish \\
\hline & & & & 2: & The size of the fish is relatively moderate \\
\hline & & & & 3: & The size is getting bigger \\
\hline \multirow[t]{3}{*}{2} & \multirow{3}{*}{$\begin{array}{l}\text { Juvenile } \\
\text { proportion }\end{array}$} & \multirow{3}{*}{$\begin{array}{l}\text { The percentage of } \\
\text { sharks caught } \\
\text { have not reached } \\
\text { adult size }\end{array}$} & \multirow[t]{3}{*}{ Observation } & $1:$ & Great many $(>60 \%)$ \\
\hline & & & & 2: & Many $(30-60 \%)$ \\
\hline & & & & $3:$ & Little $(<30 \%)$ \\
\hline \multirow[t]{3}{*}{3} & \multirow{3}{*}{$\begin{array}{l}\text { Species } \\
\text { composition }\end{array}$} & \multirow{3}{*}{$\begin{array}{l}\text { Target and non- } \\
\text { target fish species }\end{array}$} & \multirow{3}{*}{$\begin{array}{l}\text { Sampling } \\
\text { Observation }\end{array}$} & $1:$ & The proportion of target fish is getting smaller \\
\hline & & & & 2: & $\begin{array}{l}\text { The proportion of target fish is relatively the } \\
\text { same as non-target }\end{array}$ \\
\hline & & & & 3: & The proportion of non-target fish is greater \\
\hline \multirow[t]{3}{*}{4} & \multirow{3}{*}{$\begin{array}{l}\text { ETP } \\
\text { Species }\end{array}$} & \multirow{3}{*}{$\begin{array}{l}\text { ETP (Endagered, } \\
\text { Threatened and } \\
\text { Protected) } \\
\text { spesies }\end{array}$} & \multirow{3}{*}{$\begin{array}{l}\text { Sampling } \\
\text { Observation } \\
\text { Interview }\end{array}$} & 1: & $>1$ Catch of ETP species \\
\hline & & & & 2: & 1 Catch of ETP species \\
\hline & & & & $3:$ & No speseis ETP \\
\hline \multirow[t]{3}{*}{5} & \multirow{3}{*}{$\begin{array}{l}\text { Catching } \\
\text { location }\end{array}$} & \multirow[t]{3}{*}{ Fishing ground } & \multirow{3}{*}{$\begin{array}{l}\text { Survey } \\
\text { Interview }\end{array}$} & $1:$ & Fishing ground is very far \\
\hline & & & & 2: & Fishing ground far \\
\hline & & & & 3: & Fishing ground is very near \\
\hline
\end{tabular}

The domain of capture technology

\begin{tabular}{|c|c|c|c|c|}
\hline No & Indicator & Explanation & Methodology & Criteria \\
\hline 1 & $\begin{array}{l}\text { Modification of } \\
\text { fishing gear and } \\
\text { fishing aids }\end{array}$ & $\begin{array}{l}\text { The use of fishing } \\
\text { gear and tools } \\
\text { which have a } \\
\text { negative impact on } \\
\text { SDI }\end{array}$ & $\begin{array}{l}\text { Sampling the Lm (Length } \\
\text { maturity) size of sharks } \\
\text { caught through The IUCN } \\
\text { Red List of Threatened } \\
\text { Species }\end{array}$ & $\begin{array}{ll}1: \quad>50 \% \text { of shark species } \\
\\
\text { size }<\text { Lm } \\
25-50 \% \text { the size of shark } \\
\text { species }<\text { Lm } \\
3: \quad<25 \% \text { shark species size } \\
\quad<\text { Lm }\end{array}$ \\
\hline 2 & $\begin{array}{l}\text { Selectivity of fishing } \\
\text { gear }\end{array}$ & $\begin{array}{l}\text { Catching activities } \\
\text { related to the extent, } \\
\text { time, and diversity } \\
\text { of the catch }\end{array}$ & $\begin{array}{l}\text { Statistics fisheries, } \\
\text { logbook and survey }\end{array}$ & $\begin{array}{ll}\text { 1: } & \text { Low }(>75 \%) \text { use of non- } \\
\text { selective fishing gear } \\
\text { 2: }\end{array} \begin{array}{l}\text { Medium }(50-75 \%) \text { use of } \\
\text { non-selective fishing gear } \\
\text { 3: } \begin{array}{l}\text { High }(<50 \%) \text { use of non- } \\
\text { selective fishing gear }\end{array}\end{array}$ \\
\hline 3 & $\begin{array}{l}\text { Matching function } \\
\text { and size of fishing } \\
\text { boat with legal } \\
\text { documents }\end{array}$ & $\begin{array}{l}\text { Whether or not the } \\
\text { function and size of } \\
\text { the ship is in } \\
\text { accordance with } \\
\text { legal documents }\end{array}$ & $\begin{array}{l}\text { Survey / monitoring } \\
\text { function, size and number } \\
\text { of vessels. It takes } \\
\text { knowledge of how to } \\
\text { measure and information } \\
\text { on dimensions and weight } \\
\text { ratios of GT ships in the } \\
\text { field }\end{array}$ & $\begin{array}{l}\text { 1: The suitability is low (> } \\
50 \% \text { of the sample does } \\
\text { not comply with legal } \\
\text { documents); } \\
2: \quad \text { The suitability is medium } \\
\text { (30-50\% of the sample } \\
\text { does not comply with legal } \\
\text { documents); } \\
\text { 3: The suitability is high (less } \\
\text { than } 30 \% \text { ) the sample does } \\
\text { not comply with legal } \\
\text { documents }\end{array}$ \\
\hline 4 & $\begin{array}{l}\text { Certification of } \\
\text { fishing vessel crews } \\
\text { in accordance with } \\
\text { regulations }\end{array}$ & $\begin{array}{l}\text { Qualifications of } \\
\text { fishing boat crew } \\
\text { skills }\end{array}$ & $\begin{array}{l}\text { Certificate ownership } \\
\text { sampling }\end{array}$ & $\begin{array}{ll}\text { 1: } & \text { Ownership certificate } \\
& <50 \% \\
\text { 2: } & \text { Ownership certificate } 50- \\
& 75 \% \\
\text { 3: } & \text { Ownership certificate } \\
& >75 \%\end{array}$ \\
\hline
\end{tabular}




\section{Size of sharks caught}

Table 3. Size and number of sharks caught by fishermen during the study

\begin{tabular}{|c|c|c|c|}
\hline Location & Species & $\begin{array}{l}\text { Total } \\
\text { Fish }\end{array}$ & $\begin{array}{l}\text { Length } \\
(\mathrm{cm})\end{array}$ \\
\hline \multirow{4}{*}{$\begin{array}{l}\text { Tarupa } \\
\text { Island }\end{array}$} & Charcharhinus & \multirow{2}{*}{15} & $83.7-$ \\
\hline & sorrah & & 216 \\
\hline & Charhcarhinus & \multirow{2}{*}{3} & 88.9- \\
\hline & melapnoterus & & 93.26 \\
\hline \multirow{3}{*}{$\begin{array}{l}\text { Rajuni } \\
\text { Island }\end{array}$} & Charcharhinus & 2 & $87-85$ \\
\hline & Sorrah & 2 & $0 /-0 J$ \\
\hline & Nerbius ferruhineus & 1 & 175 \\
\hline \multirow{4}{*}{$\begin{array}{l}\text { Polassi } \\
\text { Island }\end{array}$} & Charcharhinus & \multirow{2}{*}{8} & $35-$ \\
\hline & Sorrah & & 103.7 \\
\hline & $\begin{array}{l}\text { Charcharhinus } \\
\text { melapnoterus }\end{array}$ & 1 & 76 \\
\hline & Nerbius ferruhineus & 3 & $\begin{array}{l}87- \\
112.2\end{array}$ \\
\hline $\begin{array}{l}\text { Kayuadi } \\
\text { Island }\end{array}$ & $\begin{array}{l}\text { Charcharhinus } \\
\text { melapnoterus }\end{array}$ & 5 & $20-78$ \\
\hline Total & & 38 & \\
\hline
\end{tabular}

The distribution of shark length that was predominantly caught by fishermen tended to vary. Sharks from Carcharhinus sorrah species are the most caught with a size of $83.7-216 \mathrm{~cm}$ in 15 heads on Tarupa Island, size $87-95 \mathrm{~cm}$ in 2 heads on Rajuni Island and on Polassi Island the size of captured is $35-103,7 \mathrm{~cm}$ totaling 8 birds. The same tendency is also found in species Carcharhinus melapnoterus which is the most species caught of fishermen who come from Kayuadi Island at birth size range from 20 to $78 \mathrm{~cm}$ by 5 , size 88.9 to 93.26 $\mathrm{cm}$ by 3 in Tarupa Island and measuring $76 \mathrm{~cm}$ by 1 animal on Polassi Island. In addition, species of Nerbius ferrugineuswere also found in Rajuni Island with a length of $175 \mathrm{~cm}$ and 1 length and range from 87-112.2 on Polassi Island with 3 tails (Table 3). Based on the NWAF EAFM indicator module, this indicator gets a score of 1 .

\section{Juvenile proportions}

The proportion of juvenile catches of fishermen was 2 species, Carcharhinus sorrahout species of a total of 25 heads, Carcharhinus melapnoterus species there were 4 juveniles out of 9 total catches, so the proportion of juvenile catches by fishermen is $52.44 \%$ (Table 4). Based on the NWAF EAFM indicator module, this indicator gets a score of 2 .

\section{Species composition}

Carcharhinus sorrah species was the dominant species caught with the number 15 Tarupa tail Island, 2 goats on the island Rajuni and 8 tail PolassiIsland. Carcharhinus melapnoterus species had a total catch of 3 in Tarupa Island, 1 in Polassi
Island and 5 in Kayuadi Island. Nerbius ferrugineus species were 1 in Rajuni Island and 3 in Polassi Island. So the composition of the shark species caught was relatively the same (Table 5). Based on the NWAF EAFM indicator module, this indicator gets a score of 2 .

Table 4. Number of juvenile catches

\begin{tabular}{|c|c|c|c|c|c|}
\hline \multirow{4}{*}{$\begin{array}{l}\text { Species } \\
\\
\text { Charcharhinus } \\
\text { sorrah } \\
\text { Charcharhinus } \\
\text { melapnoterus } \\
\text { Nerbius } \\
\text { ferruhineus }\end{array}$} & \multirow{2}{*}{$\begin{array}{l}\begin{array}{l}\text { Size of } \\
\text { juveniles } \\
(\mathrm{cm})\end{array} \\
50-55\end{array}$} & \multirow{2}{*}{$\begin{array}{l}\begin{array}{l}\text { Number } \\
\text { of } \\
\text { juveniles }\end{array} \\
2\end{array}$} & \multicolumn{2}{|c|}{$\begin{array}{l}\text { Number } \\
\text { of } \\
\text { catches }\end{array}$} & 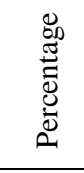 \\
\hline & & & \multicolumn{2}{|l|}{25} & 8 \\
\hline & $48-50$ & 4 & \multicolumn{2}{|l|}{9} & 44.44 \\
\hline & $40-60$ & 0 & \multicolumn{2}{|l|}{4} & 0 \\
\hline \multicolumn{5}{|l|}{ Total } & 52.44 \\
\hline \multicolumn{6}{|c|}{ able 5. Types fishermen catch sharks } \\
\hline Location & \multicolumn{3}{|l|}{ Species } & \multicolumn{2}{|c|}{ Total Fish } \\
\hline Tarupa Island & \multicolumn{3}{|c|}{$\begin{array}{l}\text { Charcharhinus sorrah } \\
\text { Charcharhinus } \\
\text { melapnoterus }\end{array}$} & \multicolumn{2}{|l|}{15} \\
\hline \multirow[t]{2}{*}{ Rajuni Island } & \multicolumn{3}{|c|}{ Charcharhinus Sorrah } & 2 & \\
\hline & Nerbius & ferruhineus & & 1 & \\
\hline \multirow[t]{2}{*}{ Polassi Island } & \multicolumn{3}{|c|}{$\begin{array}{l}\text { Charcharhinus Sorrah } \\
\text { Charcharhinus } \\
\text { melapnoterus }\end{array}$} & 8 & \\
\hline & \multicolumn{2}{|c|}{$\begin{array}{l}\text { Nerbius ferruhineus } \\
\text { Charcharhinus }\end{array}$} & & 3 & \\
\hline Total & & & & 38 & \\
\hline
\end{tabular}

\section{ETP species}

In the IUCN red list, there are several statuses given to shark species according to the conditions of their resources in the world.

Table 6. Conservation status of sharks caught by fishermen

\begin{tabular}{lll}
\hline Family & Other Name & Status* \\
\hline Carcharhinidae & $\begin{array}{l}\text { Charcharhinus } \\
\text { sorrah }\end{array}$ & NT \\
Carcharhinidae & $\begin{array}{l}\text { Charcharhinus } \\
\text { melapnoterus }\end{array}$ & NT \\
Ginglymistomatidae & $\begin{array}{l}\text { Nerbius } \\
\text { ferruhineus }\end{array}$ & VU \\
\hline
\end{tabular}

The types of sharks caught consist of 2 families. From the Carcharhinidae family, 2 species were found, namely Carcharhinus sorrah or local name and Carcharhinus melapnoterus. In the Ginglymostomatidae family, 1 species was found, 
namely Nerbius ferrugineus. According to White et al., (2006), species are Carcharhinus sorrah and Carcharhinus melapnoterus classified as Near Threatened (NT) or Near Threatened, while species are Nerbius ferrugineus classified as vulnerable (VU) or extinct (Table 6). Based on the NWAF EAFM indicator module, this indicator gets a score of 1 .

\section{Catching Location}

Determination of fishing ground location in shark fishing is based on the distance of the fishing base location from each fisherman. Fishermen from Tarupa Island were located in Jinato Island, Passitallu Island, Belang-belang Island, Karumpa
Island, Tarupa Island, Rajaka Taka, Tumbor Taka, Taka Gantarang, Taka Lamungan, Taka Lasalimu, Taka Silebu, Taka Bubbo and Taka Terros (Figure $6)$. The fishermen who came from Rajuni Island were located in Taka Gantarang, Taka Lamungan, Taka Silebu, Taka Lasalimu, Taka Rajuni, Taka Bongko, Tinanja Island, Gusung Bunging Belle and Bonerate Island (Figure 7).

Fishermen from Polassi Island and Kayuadi Island are located near the waters of the island (Figure 8 and Figure 9). Based on the NWAF EAFM indicator module, this indicator gets a score of 3 . Analysis of the data in the fish resource domain can be seen in Table 7 .

Table 7. Results of the analysis of the fish resource domain

\begin{tabular}{|c|c|c|c|c|c|c|}
\hline No. & Indicator & Weight & Score & Value & $\begin{array}{l}\text { Composite } \\
\text { Value }\end{array}$ & Description \\
\hline 1 & Size of shark caught & 30 & 1 & 30 & \multirow{5}{*}{55} & \\
\hline 2 & Juvenile proportion & 25 & 2 & 50 & & \\
\hline 3 & Species composition & 20 & 2 & 40 & & \\
\hline 4 & ETP species & 15 & 1 & 15 & & \\
\hline 5 & Catching location & 10 & 3 & 30 & & \\
\hline Tota & & 100 & & & & \\
\hline
\end{tabular}

The results of the analysis of the fish resource domain showed a composite value of $55 \%$ with the medium category. On the indicator of the size of the shark caught, the average dominant fish caught is getting smaller with the proportion of juveniles at $52.44 \%$. Indicators of composition of shark species caught were relatively the same as ETP species status> 1 and indicators of shark capture location were relatively fixed.

\section{Fishing Techniques Domain}

The EAFM approach in the fishing technique domain there are five attributes that become a measure of the assessment of fish resource utilization activities, namely Modification of fishing equipment and fishing aids; Matching the function and size of fishing vessels with legal documents; Fishing gear selectivity and fisheries crew certification according to regulations;

\section{Modification of fishing gear and fishing aids}

In operation, fishermen generally use fishing rods and basic longlines with varying sizes of main ropes and life buoys, and fishing line models $\mathrm{C}$ and $\mathrm{J}$ with tation numbers 5000-10000. The use of fishing gear has been used for generations to date. Longline fishing gear consists of several parts, among others:

\section{Main rope}

The main rope functions as a branch strap. Material that is often used by fishermen for nylon main ropes. The size of the main rope of a longline ranges from 9 to 375 meters.

\section{Branch cords}

Branch cords are ropes that hang on the main rope and function as a fishing ground. The material used by fishermen for basic longline branch ropes is polyethylene with a diameter of $3 \mathrm{~mm}$. The average length of a branch rope is 1.5 - 3 meters.

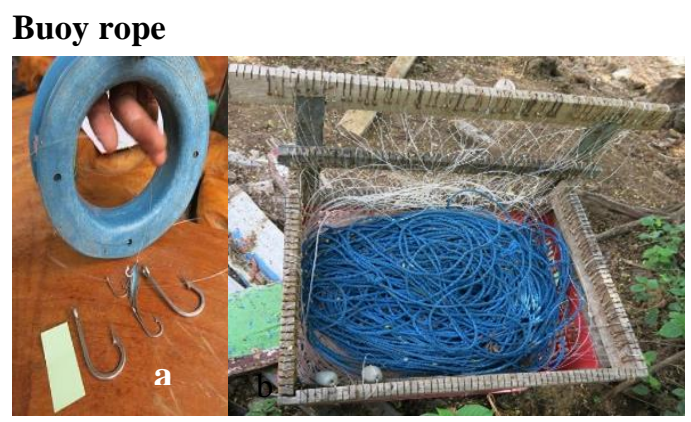

Figure 1. Sharks' fishing gear (a) Fishing line stretching; (b) Basic longline 
Buoy rope is a rope that connects the main rope with buoy. The buoy rope also functions as a determinant of the depth and position of the basic longline in the waters.

\section{Fishing line}

The fishing line is the base from which the bait depends. The fishing line models used are models $\mathrm{C}$ and $\mathrm{J}$. One basic longline unit usually ranges from 6 to 90 hooks. Based on the frequency distribution of sharks 'length of fishermen's catches can be seen in Figure 3

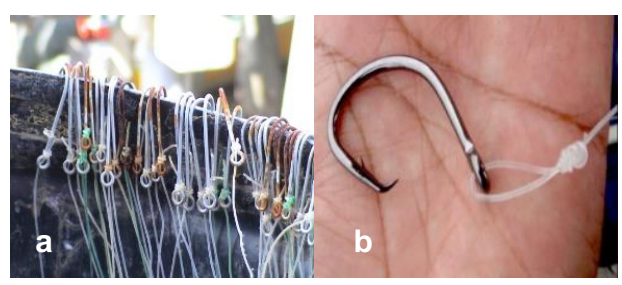

Figure 2. (a) Model of the fishing line J; (b) Fishing line model C
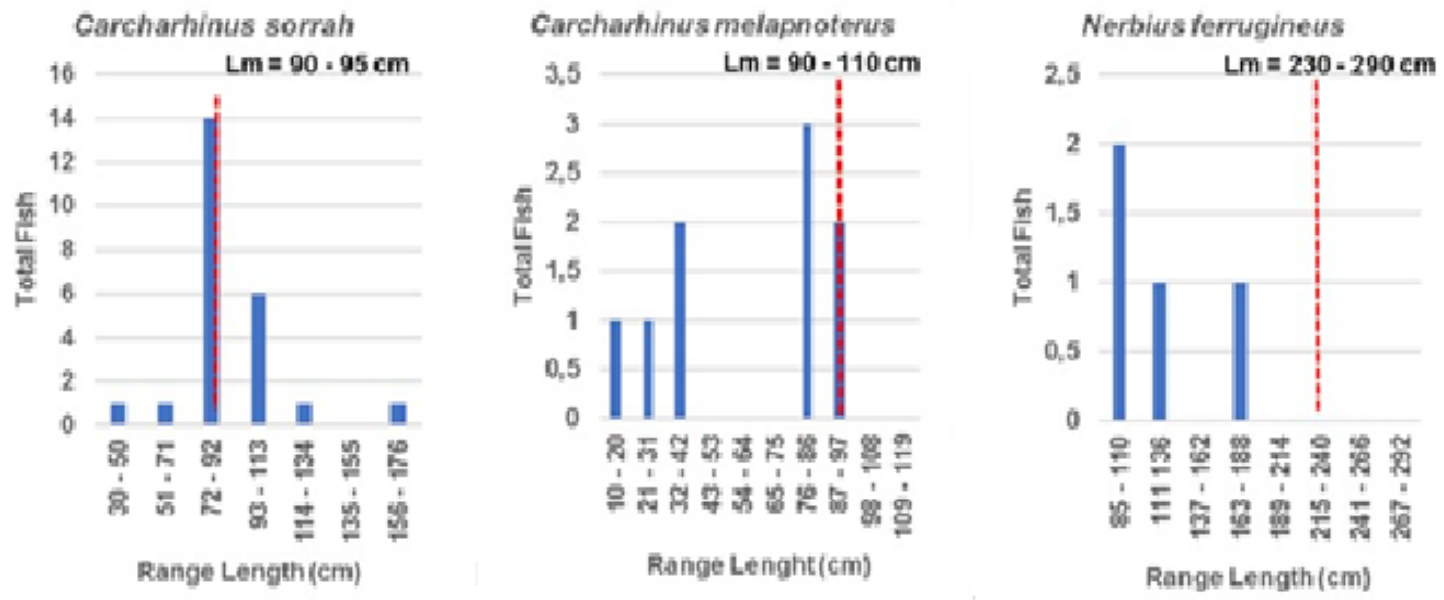

Figure 3. Distribution of sharks' length of fishermen's catches

The results of data analysis showed 25 species of Chacharhinus sorrah caught, with 6 or $24 \%$ which were small, so that the species is not feasible to catch and the rest that are worth catching as many as 19 heads or by $76 \%$. While Charchahinus melapnoterus and Nerbius ferrugenius species amount to $100 \%$ of the total catch of fishermen were also not feasible to catch (Figure 3 ). This indicated that $>50 \%$ of sharks caught by fishermen were below Lm. Based on the NWAF EAFM indicator module this indicator gets a score of 1 .

\section{Suitability of function and size of fishing vessels with legal documents}

Ships are the infrastructure of fishermen towards fishing ground. The ships are made from two main raw materials. Some ships use wood and others use fiber. The standard selection is based on the budged and fisherman skills in its operation. The specifications of fishing boats can be seen in Table 8.

Table 8. Specifications of fishing boats

\begin{tabular}{llllllll}
\hline Respondents & Location & \multicolumn{2}{c}{ Size of Ship (cm) } & Status & PK & $\begin{array}{l}\text { Document } \\
\text { Archive }\end{array}$ \\
& & long & width & height & & & \\
\hline Ambo Amin & Tarupa Island & 130 & 80 & 70 & Personal & 24 & None \\
H. Aco & Tarupa Island & 700 & 120 & 80 & Personal & 24 & None \\
Mudir & Tarupa Island & 130 & 60 & 60 & Personal & 24 & None \\
Badaruddin & Tarupa Island & 130 & 60 & 60 & Personal & 24 & None \\
H.Siding & Tarupa Island & 1050 & 65 & 100 & Personal & 30 & None \\
Suting & Tarupa Island & 700 & 120 & 80 & Personal & 30 & None \\
Armin & Rajuni Island & 850 & 140 & 70 & Personal & 24 & None \\
Taang & Polassi Island & 700 & 130 & 75 & Personal & 24 & None \\
Jasi & Kayuadi Island & 850 & 150 & 70 & Personal & 24 & None \\
\hline
\end{tabular}


Ships used in catching sharks <5 GT in various sizes. The fishing boats used were privately owned with sizes 24 and $30 \mathrm{PK}$ and all vessels do not have documents. Based on the results of interviews, ship documents were only for ships of size> 5 GT. In addition, the handling of the documents was far from where they live so that to take care of all the ship's equipment takes quite a lot of time and money. Based on the NWAF EAFM indicator module this indicator gets a score of 1 .

\section{Fishing gear selectivity}

Fishing gear selectivity was a fishing activity with an area of fishing area, length of time used and diversity of catches obtained. The interview results showed that $100 \%$ of the fishing gear used by fishermen in shark fishing operations in the waters of the Selayar Regency Islands was basic longline. In the NWAF EAFM module (2014), it states that fishing gear (longline tuna, drift longline, fixed longline, huhate, trolling line and handline fishing line) is a fishing gear that is classified as having a high level of selectivity. Based on the NWAF EAFM indicator module this indicator gets a score of 3 .

\section{Certification of fishing vessel crews is in accordance with regulations.}

In the fisheries crew certification indicators all fishing vessel crews are required to have seafaring expertise certificates such as the Nautical Fishing Vessel Certificate I / II / III (Ankapin) or the I / II / III Fishing Vessel Technical Certificate (Atkapin) depending on their respective fields respectively.

Interviews showed that all crew members operating in catching sharks are not equipped with Ankapin or Atkapin certificates. Fishermen who work on fishing vessels do not even know the certificate. Based on the NWAF EAFM indicator module this indicator gets a score of 1 . Analysis of the data in the domain of fishing techniques can be seen in Table 9.

Table 9. Results of the domain analysis of fishing techniques

\begin{tabular}{|c|c|c|c|c|c|c|}
\hline No. & Indicator & Weight & Scores & Value & $\begin{array}{l}\text { Composite } \\
\text { Value }\end{array}$ & Description \\
\hline 1 & $\begin{array}{l}\text { Modification of fishing gear and fishing } \\
\text { aids }\end{array}$ & 40 & 1 & 40 & & \\
\hline 2 & Selectivity of foshing gear & 30 & 3 & 90 & & \\
\hline 3 & $\begin{array}{l}\text { Matching function and size of fishing } \\
\text { boat with legal documents }\end{array}$ & 20 & 1 & 20 & 53 & \\
\hline 4 & $\begin{array}{l}\text { Certification of fishing vessel crews in } \\
\text { accordance with regulations }\end{array}$ & 10 & 1 & 10 & & \\
\hline Total & & 100 & & 160 & & \\
\hline
\end{tabular}

The results of the analysis of the fishing technique domain showed a composite value of $53.33 \%$ with the medium category. In the indicator of modification of fishing gear and fishing aids more than $50 \%$ the size of the target species <Lm with the selectivity of fishing gear used in shark fishing is high. Indicators of suitability of function and size of fishing vessels were not in accordance with legal documents, because all the vessels used by fishermen in shark fishing do not have documents. In addition, all crew members were not equipped with certificates.

In the domain of fish resources and fishing techniques have low values with moderate descriptions. This indicates that the indicators in the domain were mostly below the reference point, thus gaining top priority in management efforts.
Table 12. Composite analysis results EAFM

\begin{tabular}{llll}
\hline No & Domain & $\begin{array}{l}\text { Composite } \\
\text { value }\end{array}$ & Description \\
\hline 1 & Fish resources & 55.00 & \\
2 & $\begin{array}{l}\text { Fishing } \\
\text { techniques }\end{array}$ & 53.33 & \\
\hline Aggregates & 66.25 & \\
\hline
\end{tabular}

Shark fishing in Indonesia is currently in the international spotlight. Based on FAO data from 1950 to 2009, the total catch of Elasmobranch fish in the world from year to year has increased, where in 2003 was the highest catch of sharks and rays in the world which reached 800,000 tons / year and the following year decreased by $20 \%$ ( Dulvy et al. 2014). Of these, Indonesia is the largest shark producing country in the world, with a contribution of $16.8 \%$ of the total world catch (Effendi et al, 2018). 


\section{EAFM Domain}

\section{Domain of fish resources}

Sharks fishing in Indonesia is generally carried out by small-scale fishermen (Fahmi and Darmadi, 2013). Selayar Islands Regency is one of the areas that contributes to shark production in South Sulawesi. The results of the analysis of the fish resource domain showed a composite value of $55 \%$ with a moderate category (Table 7). This was because the trend in the size of sharks caught by fishermen was mostly classified as young and immature gonads (Table 3 and Appendix 6). This indicates that shark fishing in the Selayar islands had reached its maximum limit (Overfishing). Growth overfishing occurs when the catch is dominated by small fish or young fish at growth size (Diekert 2010). Furthermore Fitriya (2017), states that overfishing will lead to the condition of growth overfishing which causes a decrease in fish stock due to young fish caught that have not reached adulthood or optimum growth.

The percentage of juvenile catches caught by fishermen was $2.44 \%$ (Table 4). This indicates that the reproductive characteristics of each type of shark were not the same and the number of children born is also different, thus causing the dominance of the types of sharks caught. According to Bhagawati et al (2017), there are sharks that give birth more frequently than others. Besides that, there were also sharks that give birth to children in large numbers, so naturally the species of fish is more abundant than others, as is the case of sharks in the Carcharhinidae family, Carcharhinus sorrah and Carcharhinus melapnoterus. This situation was also reported by PPSC (2015), that during 2011 2015 shark fishing activities increased from 11 recorded species, there were four types of which were Carcharhinidae family. The diversity of the Carcharhinidae family caught showed that the family of shark species had the same behavior, living habits and distribution areas. The similarity makes it easier for fishermen to determine how to catch, the tools used and the location of fishing (Campagno, 1984). Several factors affect the number of sharks that are caught by fishermen due to the ability of fishing vessels and catchment areas (Diekert, 2010).

There are 2 family composition of fishery shark species, namely Carcharhinidae and Ginglymostomatidae. Carcharhinidae family consists of Carcharhinus sorrah and Carcharhinus melapnoterus species which are classified as Near Threatened (NT) or almost threatened. The Ginglymostomatidae family consists of Nerbius ferrugineus species that are classified as vulnerable
(VU) or vulnerable to extinction (Table 6). Fahmi and Dharmadi (2013), stated that the development of shark trade that continues to increase and the increasingly intensive catching of sharks causes some species to be vulnerable to population decline in Indonesia. Most of the shark species that are included in the IUCN (International Union for Conservation of Nature) red list.

The determination of fishing ground in catching sharks is based on the distance of the fishing base location from each fisherman. Generally, traditional fishermen catch sharks in areas not far from coastal waters and at relatively shallow depths, while small or still-sized sharks generally make coastal waters and relatively shallow waters as nursery ground (Froese, 2004) . Furthermore Effendi, et al (2018), stated that shark fishing activities are generally carried out in shallow coastal waters which are nursery and feeding grounds.

\section{Domain of fishing technique}

The results of the analysis of the fishing technique domain showed a composite value of $53.33 \%$ with medium category (Table 9). This was because the indicators for modification of fishing gear and fishing aids were more than $50 \%$ of the target species size <Lm (Figure 3 and Appendix 6). This condition has a high risk of overfishing if the fishing pressure continues. Furthermore Froose (2004), states that the proportion of maximum growth (mega spawner) with condition $>30 \%$ indicates that shark populations are in good condition with lower risk of catching, whereas if the proportion of mega spawner is less than $20 \%$ indicates the population is likely affected fisheries due to catch are more on size of immature gonads or overfishing recruitment (Froese, 2004).

The indicators of the suitability of ship functions and the size of fishing vessels with legal documents showed that the vessels used by fishermen in shark fishing are <5 GT in size. The longline fishing boat was privately owned with a machine size of 24-30 PK and all ships do not have documents (Table 8 and Appendix 1). Based on the results of interviews, ship documents were only for ships of size> 5 GT. In addition, the handling of the documents was far from where they live so that to take care of all the ship's equipment took quite a lot of time and money. According to Gillet (2011), small scale fishermen can be seen from the tonnage size of the fishing fleet $<5 \mathrm{GT}$, the distance to the location of fishing ground is not more than 3 miles from the coast to the sea, the type of machine used is below $60 \mathrm{PK}$. The main fishing gear used by shark fishing vessels in the waters of the Selayar Regency Islands was the basic longline (Figure 1). According to Sudirman and 
Mallawa (2004), longline fishing gear consists of a series of main lines, a float and a float line where at the main rope at a certain distance there were several shorter branch lines and smaller in diameter, and at the end of the branch rope there is a hook. Longline fishing rods consist of two types, namely longline mounted at the bottom of the water within a certain period of time (bottom or set long line) and which was mounted on the surface and drifted with the current (surface or drift long line). The decrease in fishing gear (setting) and withdrawal (hauling) is done manually (human power) without using tools (line hauler). This was because shark fishing vessels owned by fishermen are categorized as artisanal / traditional vessels so that all the processes and technologies used are still relatively simple. According to Sentosa (2016), catching sharks with surface longlines by fishermen is included in the artisanal fisheries category which has limiting factors in the form of bait and accommodation costs.

Fishing selectivity is a fishing activity that is related to the extent of the fishing area, the length of time used and the diversity of catches obtained (Wahid, 2019). Judging from the selectivity, longline fishing gear was a fishing gear that is classified as high selectivity. Based on the EAFM module (2014), fishing gear (longline tuna, drift longline, fixed longline, huhate, trolling line and handline) is a fishing gear that is classified as having a high level of selectivity. According to Wahid (2019), sustainable fisheries will be hampered if there are no boundaries for fishing areas, making it difficult for fish to find breeding grounds and grow. If the fishing activities were carried out throughout the year, the fish will lose time to grow and if there is no regulation of the type of fishing gear, the diversity of fish will decrease.

Interview results also showed that all crew members operating in shark fishing were not equipped with an Nautical Fishing Boat Expert (ANKAPIN) or a Fishing Boat Technician (ATKAPIN). This was because fishermen and boat crews who work in catching sharks do not even know the certificate. According to Monintja (2016), various basic requirements in participating in certification activities are quite difficult given by fishermen because of the limited formal education completed. One of the regulations governing ship crew certification is KEPMENHUB No.9 of 2005 concerning Education and Training, Exams and Certification for Seafarers of Fishing Vessels, Certificates of Expertise (Certifcate of Profession / COP) explained that fishing vessel crews consist of Nautical Fishing Vessels (ANKAPIN) for deck officers and Level Fishing Boat Engineers
(ATKAPIN) for engine officers. The certification quality test standards refer to the 1995 International Training of Certified Watchkeeping-Fisheries (STCW-F) regulations from the International Maritime Organization (IMO). The authority of the fishing vessel crew is based on three main factors namely the Gross Tonage (GT) of the ship (minimum $30 \mathrm{GT}$ ), the length of the ship $\langle 12 \mathrm{~m}\rangle$ $24 \mathrm{~m}$ and the area of shipping operations ( $<60$ miles - EEZ). So when referring to these criteria, sharkcatching fishermen in the Selayar Archipelago do not qualify as required to have a certificate because ships operated by fishermen to catch sharks are small and can be operated by just one person. The skills of the various types of work they have come from informal experience when participating in and watching parents go to sea.

\section{Application of EAFM in shark management}

Assessment of EAFM indicators refers to the National Working Group on Ecocytem Approach to Fisheries Management, Directorate of Fish Resources, Ministry of Maritime Affairs and Fisheries (2014). The assessment results show that the status of shark fisheries management in the Selayar Islands District was in the medium category (Table 12). The current category in management status shows that shark fisheries in the Selayar Islands Regency had not experienced a decline, but more intensive management efforts were needed to support the sustainability of resources. Puspasari et al (2014), stated that in the effort to implement EAFM there are 4 steps that must be carried out after assessing the indicators, namely (1) determining the main issues, (2) setting operational objectives, (3) implementing management and (4) monitoring evaluation. Monitoring and evaluation is carried out after the implementation process, so it is not discussed in this study.

Determination of the main issues is based on scoring and weighting of each indicator by the method used by Fletcher (2011). Furthermore Puspasari et al., (2014), states that the main issue is determined from indicators that have high weights with low scores. From the results of the analysis, three main issues and management of shark fisheries were determined from four domains which can be seen in Table 13 .

Recommendations compiled based on the results of the assessment of the EAFM indicator is needed in order to improve conditions that are still lacking or moderate (Wahid et al, 2019). For the fish resource domain there were a number of recommendations, namely making regulations on the minimum size of sharks that can be caught by first conducting a scientific study related to these sizes and socializing 
in the form of a Foccus Group Discussion (FGD) to shark fishermen related to the size and type of sharks that are worth catching and the status of each type of shark. For the domain of fishing techniques the recommendation was the rule of type and classification of assistive technology that supports the precautionary principle in the use of fish resources.

Table 13. Management steps in shark resource utilization

\begin{tabular}{|c|c|c|}
\hline $\begin{array}{l}\text { Main } \\
\text { Issues }\end{array}$ & $\begin{array}{l}\text { Operational } \\
\text { objectives }\end{array}$ & $\begin{array}{l}\text { Management } \\
\text { implementation }\end{array}$ \\
\hline $\begin{array}{l}\text { Sharks size } \\
\text { gets } \\
\text { smaller }\end{array}$ & $\begin{array}{l}\text { Increases the } \\
\text { size of shark } \\
\text { catches }\end{array}$ & $\begin{array}{l}\text { Making regulations } \\
\text { on the minimum } \\
\text { size of sharks that } \\
\text { can be caught by } \\
\text { conducting prior } \\
\text { scientific studies } \\
\text { related to these } \\
\text { sizes } \\
\text { Socialization in the } \\
\text { form of FGD to } \\
\text { shark fishermen }\end{array}$ \\
\hline $\begin{array}{l}\text { Catches of } \\
\text { sharks } \\
\text { were not } \\
\text { worth } \\
\text { fishing } \\
(50 \% \text { of } \\
\text { the catch } \\
<\mathrm{Lm})\end{array}$ & $\begin{array}{l}\text { Boosting the } \\
\text { catch sharks } \\
\text { worth catching }\end{array}$ & $\begin{array}{l}\text { Rule types and } \\
\text { classification } \\
\text { technology tools } \\
\text { that support the } \\
\text { principle of } \\
\text { prudence in the } \\
\text { utilization of fish } \\
\text { resources } \\
\text { Socialization in the } \\
\text { form of FGD on } \\
\text { fishermen catching } \\
\text { sharks }\end{array}$ \\
\hline
\end{tabular}

\section{CONCLUSION}

Shark resource stock had decreased in catch which was characterized by the average size of the catch getting smaller with a juvenile proportion of $52.44 \%$, the composition of the shark species caught was relatively the same as the status of Near Threatened (NT) or Near Threatened and Vulnerable (VU) or are vulnerable to extinction and the location of shark capture was relatively fixed.

The modification of fishing gear and fishing aids of more than $50 \%$ of target species size < Lm with the selectivity of fishing gear used in shark fishing were high, the suitability of the function and size of fishing vessels were not in accordance with legal documents, besides all the vessels used by fishermen catching sharks has no documents. In addition, all crew members were not equipped with certificates.

\section{REFERENCES}

Bhagawati, D., T. Nurani, M. N Abulias. 2017. Jenis, performa dan nisbah kelamin ikan hiu yang didaratkan di Pelabuhan Perikanan
Samudra Cilacap. Jurnal Iktiologi Indonesia. 17(2): 185-200

Campagno, L.J.V. 1984. FAO Spesies Catalogue. Vol 4. Shark of the world. An Annoted Illustrate Catalogue of Shark Spesies Known to Date. Part I "Hexanchiformes to Lamniformes". FAO Fish.

Diekert, F.K. 2010. Growth overfishing. IIFET 2010. Montpellier Proceedings. 1-12

Dulvy, N. K., Fowler, S.L., Musick, J.A., Cavanagh, R. D., Kyne, P. M., Harrison, L. R., Carlson, J. K., Davisdson, L. N. K., Fordham, S.V., Francis, M. P., Pollock, C. M., Simpfendorfer, C. A., Burgess, G. H., Carpenter, K. E., Compagno, L. V. J., Ebert, D. A., Gibson, C., Heupel, M. R., Livingstone, S. R., Sanciangco, J. C., Stevens, J. D., Valenti, S. and White, W. T. 2014. Extinction risk and conservation of the world's sharks and rays. Research Intitute for the Environment and Liverlihoods (eLIFE) 3: 1 - 34

Effendi, H. P., R. T. Dhewi, Ricky. 2018. Keragaman jenis dan distribusi panjang ikan hiu di perairan Selat Makassar. Prosiding Simposium Nasional Hiu Pari Indonesia (II): 33- 42

Fahmi dan Dharmadi. 2013. Tinjauan Status Perikanan Hiu dan Upaya Konservasinya di Indonesia. Direktorat Konservasi Kawasan dan Jenis Ikan. Kementerian Kelautan Perikanan Republik Indonesia.

Fletcher, W. J., J. Shaw, D. J.Gaughan \& S. J. Metcalf. 2011. Ecosystem Based Fisheries Management case study report - West Coast Bioregion. 116 pp.

Froese, R. 2004. Keep is Simple; there indicators to deal with overfishing. Fish and Fisheries (5), 86-91

Gillett R. 2011. Bycatch in Small-scale Tuna Fisheries: a Global Study. FAO Fisheries and Aquaculture Technical Paper. No. 560. Rome

KEPMEN-KP. 2013. Keputusan Menteri Kelautan dan Perikanan Republik Indonesia Nomor 18/KEPMEN-KP/2013 tentang Penetapan Status Perlindungan Penuh Ikan Hiu Paus (Rhincodon typus). Menteri Kelautan dan Perikanan Republik Indonesia. Jakarta.

Monintja., E. S. 2016. Penilaian pengelolaan perikanan berdasarkan indikator teknik penangkapan ikan dan kelembagaan ecosystem approach for fisheries 
management [Skripsi]. Program Studi Teknologi dan Manajemen Perikanan Tangkap. Fakultas Perikanan dan Ilmu Kelautan. Institut Pertanian Bogor. Bogor.

NWG EAFM. 2014. Modul penilaian indikator untuk perikanan dengan pendekatan ekosistem. National Working Group on Ecosystem Approach to Fisheries Management. Direktorat Sumber Daya Ikan. Kementerian Kelautan Perikanan Republik Indonesia.

PERMEN-KP. 2014. Peraturan Menteri Kelautan dan Perikanan Republik Indonesia Nomor 59/PERMEN-KP/2014 tentang Ikan Hiu Koboi (Carcharhinus longimanus) dan Hiu Martil (Sphyrna spp.) dari Wilayah Negara Republik Indonesia ke Luar Wilayah Negara Republik Indonesia. Menteri Kelautan dan Perikanan Republik Indonesia. Jakarta.

PERPRES RI.. 1990. Undang-Undang Republik Indonesia Nomor 5 Tahun 1990 tentang Konservasi Sumber Daya Alam Hayati dan Ekosistemnya (Lembaran Negara Republik Indonesia Tahun 1990 Nomor 49). Jakarta

PPSC (Pelabuhan Perikanan Samudera Cilacap). 2015. Laporan Tahunan 2010-2014, Kementerian Kelautan dan Perikanan, Direktorat Jenderal Perikanan Tangkap.
Kementerian Kelautan Perikanan Republik Indonesia. Cilacap. $40 \mathrm{hlm}$.

Puspasari, R., Wudianto, R. Faizah. 2014. Penerapan EAFM dalam pengelolaan perikanan malalugis Decapterus macarellus di perairan Laut Sulawesi. Jurnal Kebijakan Perikanan Indonesia. 6(1) : 29-36.

Sentosa. A. A. 2016. Profil penangkapan hiu oleh kapal nelayan rawai permukaan di perairan barat Pulau Sumba. Seminar Nasional Tahunan XIII. PI (17) :315-326.

Sudirman dan Mallawa, A. 2004. Teknik Penangkapan Ikan. PT. Rineka Cipta. Jakarta.

Wahid. N. I., 2019. Pengelolaan Perikanan Pelagis Besar dengan Pendekatan Ekosistem di Kabupaten Mamuju Utara, Sulawesi Barat [THESIS]. Program Pascasarjana. Universitas Terbuka. Jakarta

White, W.T., Last, P. R. Stevens, J. D. Yearsley, Fahmi dan Dharmadi. 2006. Economically important sharks and rays of Indonesia. ACIAR. 329 p

WWF Indonesia. 2016. Better Management Practices, Seri Panduan Perikanan Bycatch. Panduan Penanganan Hiu Sebagai Tangkapan Sampingan (Bycatch) Edisi 